Article

\title{
Evaluation of the PAH Content in Soot from Solid Fuels Combustion in Low Power Boilers
}

\author{
Ewa Szatyłowicz * (D) and Iwona Skoczko
}

Department of Technology and System Environmental Engineering, Faculty of Civil and Environmental Engineering, Bialystok University of Technology, Wiejska 45A, 15-351 Bialystok, Poland; i.skoczko@pb.edu.pl

* Correspondence: e.szatylowicz@pb.edu.pl; Tel.: +48-571-443-151

Received: 8 October 2019; Accepted: 6 November 2019; Published: 8 November 2019

\begin{abstract}
The emission of carbon compounds (in the form of soot) to the atmosphere has a significant impact on the environment and human health. Air pollution with combustion products, having a unique combination of physical and chemical properties, is an important component of very fine suspended dust, which is emitted from various sources related to combustion processes. The carbon compounds in aerosol form and deposited in the substrate are found all over the Earth. The paper presents results of comparative research on the content of 16 polycyclic aromatic hydrocarbons (PAH) in soot samples obtained as a result of combustion of solid fuels such as hard coal with granulation above $60 \mathrm{~mm}$, coal with a grain size of $25-80 \mathrm{~mm}$, coal with a grain size of $8-25 \mathrm{~mm}$, pellets and dry wood. On the basis of the conducted tests, it was found that the soot obtained in the combustion of coal in different granulation contains more cytotoxic PAH in comparison to the combustion of wood pellets or dry firewood.
\end{abstract}

Keywords: solid fuels; combustion; soot; PAH

\section{Introduction}

Emission of carbon compounds in the form of soot to the atmosphere has a significant impact on the environment and human health. Soot is a form of air pollution that has a unique combination of physical and chemical properties. It is also an important component of very fine suspended dust, which is emitted from various sources related to combustion processes [1]. Often in literature, soot compounds are referred as elemental carbon (EC); alternative names are black carbon (BC) or black smoke. Soot is a toxic waste produced mainly as a result of low emissions, i.e., in the combustion processes of solid fuels and waste in individual heat sources. Here, the term 'low emissions' is used to describe harmful dust and gas emissions at low altitude. These are emitters such as chimneys and other emission sources located at a height not exceeding $40 \mathrm{~m}[2,3]$. Other sources of soot in the environment include emission of pollutants from vehicles and vessels with diesel engines, production of energy and heat in the power industry, production of heat in industry, forest fires and biomass burning in agriculture [1,4-8]. This waste consists of highly toxic, carcinogenic or mutagenic compounds, including amorphous carbon, graphite-like connections, fullerenes, ashes, and metal compounds, including heavy metals and metalloids. In addition, hydrocarbons, in particular aliphatic and aromatic hydrocarbons, including large amounts of polycyclic aromatic hydrocarbons (PAH), constitute a large proportion of the soot $[4,5]$.

Chemical composition of soot depends on the fuel composition and the physicochemical conditions of the combustion process [9-11].

The formation of soot begins with the reaction of the decomposition of fuel molecules, i.e., the pyrolysis and oxidation reactions. Then, there are recombination and cyclization reactions that lead to the formation of polycyclic aromatic hydrocarbons. On the other hand, the increase in PAH 
in flames occurs through the repetitive hydrogen abstraction and acetylene addition, known as the hydrogen and acetylene addition mechanism (HACA) [5,6]. The soot particles under the microscope resemble a layer structure formed from condensed six- and five-membered rings. The presence of these rings causes the expanding layers to develop into spherical structures with a diameter of several dozen nanometers. Research conducted by the group of Schultz confirms the large variety of aromatic compounds involved in the formation of the initial soot particles. In addition, Schultz proved that penta rings often occur during black carbon formation and that non-aromatic side groups such as cycloaliphatic moieties, methyl groups and alkyl chains also occur [5]. In contrast, Commodo and others confirmed that in the black carbon formed at the beginning of soot creation process there are molecules containing condensed six-ring units (formed in the flame) organized in almost completely peri-condensed structures and several molecules showing aliphatic side groups-mainly methyl groups $\left(-\mathrm{CH}_{3}\right)[6]$.

A well-developed specific surface of soot translates into a high adsorption capacity. Along with soot, other toxic substances are transferred. Due to its very low density $\left(1.3 \mathrm{~g} / \mathrm{cm}^{3}\right.$ [12]), it can persist in the atmosphere for a long time. Small size of soot particles (soot is part of the PM10 and PM2.5 dust) makes it able to penetrate the body's barrier, penetrating not only through the airways, but sometimes even through the skin [13-15]. Medical research conducted in this direction has shown that it can cause mutagenic and carcinogenic changes in the human body, as well as cardiovascular and respiratory diseases $[16,17]$.

In addition, soot is considered a factor affecting the climate of the Earth. Initially, the share of soot in this area was treated very slightly, and all attention was focused mainly on carbon dioxide as the main factor contributing to global warming. Recent scientific studies show that soot is the second most important factor that influences the current climate change after carbon dioxide. An additional feature of $B C$ is that it absorbs sunlight [18-29]. Absorbed energy is released in the form of heat and thus contributes to the warming of air, which results in the acceleration of melting ice and snow [5]. In addition, soot affects the climate change through such processes as cloud formation, water evaporation and disappearance, or precipitation [18-20].

According to researchers' forecasts and trends of changes obtained in international research centers, the soot emission in Europe has significantly decreased, based on inventory and measurements from soot emission sources, but the structure of emission sources has changed. An increase in emissions in the municipal and household sector in the overall carbon pollution balance was observed. This phenomenon is caused by a greater share of organic carbon in the dust emitted from the combustion of solid fuels in energy and emission inefficiencies in installations. This is connected with the dominating share of solid fuels, i.e., coal and biomass in the fuel structure of the municipal sector in Eastern Europe and a large share of diesel-powered vehicles in Western Europe [20]. However, in Poland, according to the report prepared by The National Centre For Emissions Management of The Institute of Environmental Protection-National Research Institute (IEPNRI), published in 2018, the volume of emissions of the BC dust soot fraction increased in 2015-2016. The emission of BC dust fractions in 2016 increased by approximately $7 \%$ compared to 2015, mainly due to higher consumption of fuels in the sector of combustion processes outside the industry and in road transport [21].

In connection with the above, this research was undertaken to assess the content of 16 individual representatives of the polycyclic aromatic hydrocarbons (PAH) group in soot from the combustion of various solid fuels in the low power boilers. Therefore, samples of soot selected for testing were from the combustion of imported hard coal with dimensions over $60 \mathrm{~mm}$, hard coal with a grain size of $25-80 \mathrm{~mm}$, bituminous coal with a grain size of $8-25 \mathrm{~mm}$, pellets with a grain size of $6 \mathrm{~mm}$ and mixed firewood. The content of the $\Sigma$ LMW (low molecular weight polycyclic aromatic hydrocarbons) fraction containing the hydrocarbons containing in their structure from two to four aromatic rings, $\Sigma$ HMW (high molecular weight polycyclic aromatic hydrocarbons with concentrations of five- and six-ring hydrocarbons) and $\Sigma 16 \mathrm{PAH}$ (total content of 16 polycyclic aromatic hydrocarbons in the sample) were taken into account. This measure of the content of the 16 compounds from the PAH 
group is recommended for monitoring in the environment by Environmental Protection Agency (EPA) as it encompasses the most potent carcinogenic and mutagenic properties. Therefore, it was decided to evaluate the content of $\mathrm{PAH}$ in soot samples from the combustion of solid fuels in a low power class 5 boiler that met the eco-design standards. The potential for reducing emissions of soot and its components depends on technical and non-technical solutions that should be applied in the sector of human activity bringing the largest load of soot to the air [20].

In addition, the carcinogenicity equivalent (CEQ) and selected mutagenic and toxic equivalents of the TCDD-TEQ (the 2,3,7,8-tetrachlorodibenzo-p-dioxin (TCDD) toxic equivalent quantity) interaction of the PAH mixture and the $\Sigma \mathrm{PAH}_{\mathrm{car}} / \Sigma \mathrm{PAH}$ ratio (ratio of the sum of carcinogenic PAH to the sum of PAH determined) for all types obtained from the combustion of solid carbonaceous fuels were calculated.

\section{Materials and Methods}

The tests were carried out by burning the following fuels: hard coal with a size of over $60 \mathrm{~mm}$, hard coal with a grain size of $25-80 \mathrm{~mm}$, hard coal with a granulation of $8-25 \mathrm{~mm}$, pellets with a grain size of $6 \mathrm{~mm}$ and mixed firewood. The combustion process was carried out on a laboratory bench [22] (Figure 1) consisting of Moderator Unica Vento Eko boiler $25 \mathrm{~kW}$ with an automatic feeder equipped with a manual and retort grate. The temperature of the feed water (at the boiler's outlet) was about $70-80^{\circ} \mathrm{C}$, while at the return it was not less than $50^{\circ} \mathrm{C}$.

The moderator is a boiler with a transverse circulation chamber working with upper combustion. The walls are water cooled and made of quality $5 / 6 \mathrm{~mm}$ sheet steel and a $4 \mathrm{~mm}$ outer shell. The cubical exchanger consists of a chamber with a self-cleaning retort furnace, above which there is a flue gas deflector (Figure 1). The deflector is an essential element of the retort furnace-it serves as a "flue gas accelerator". The remaining part of the exchanger consists of heat plates which effectively receive the heat from the flowing flue gases. The boiler is thermally insulated and has a chassis. In addition, it has a retort furnace door and loading door (for alternative fuel). Soot for further testing was taken from the door for cleaning the boiler chambers, located on the front wall of the boiler. Next to the boiler there is a fuel container mounted on the feeder unit. The feeder unit is powered by a motoreducer via an electrical motor (Figure 1). Mounted on the boiler there also is an electronic controller, which allows for a fully automatic control of the boiler operation. The engine powering the screw via the motoreducer is turned on and off by the controller based on the temperature read from sensors; the blow fan is activated accordingly. The screw transports the fuel to the boiler where it is burned in the furnace with a supply of air through the openings in the top.

Three events of combustion were carried out for each of the five solid fuels selected for testing, collecting measurements each day from the heat exchanger (Figure 1). Each time, $15 \mathrm{~kg}$ of each fuel was burned, maintaining the same combustion conditions, i.e., temperature of the fumes. 


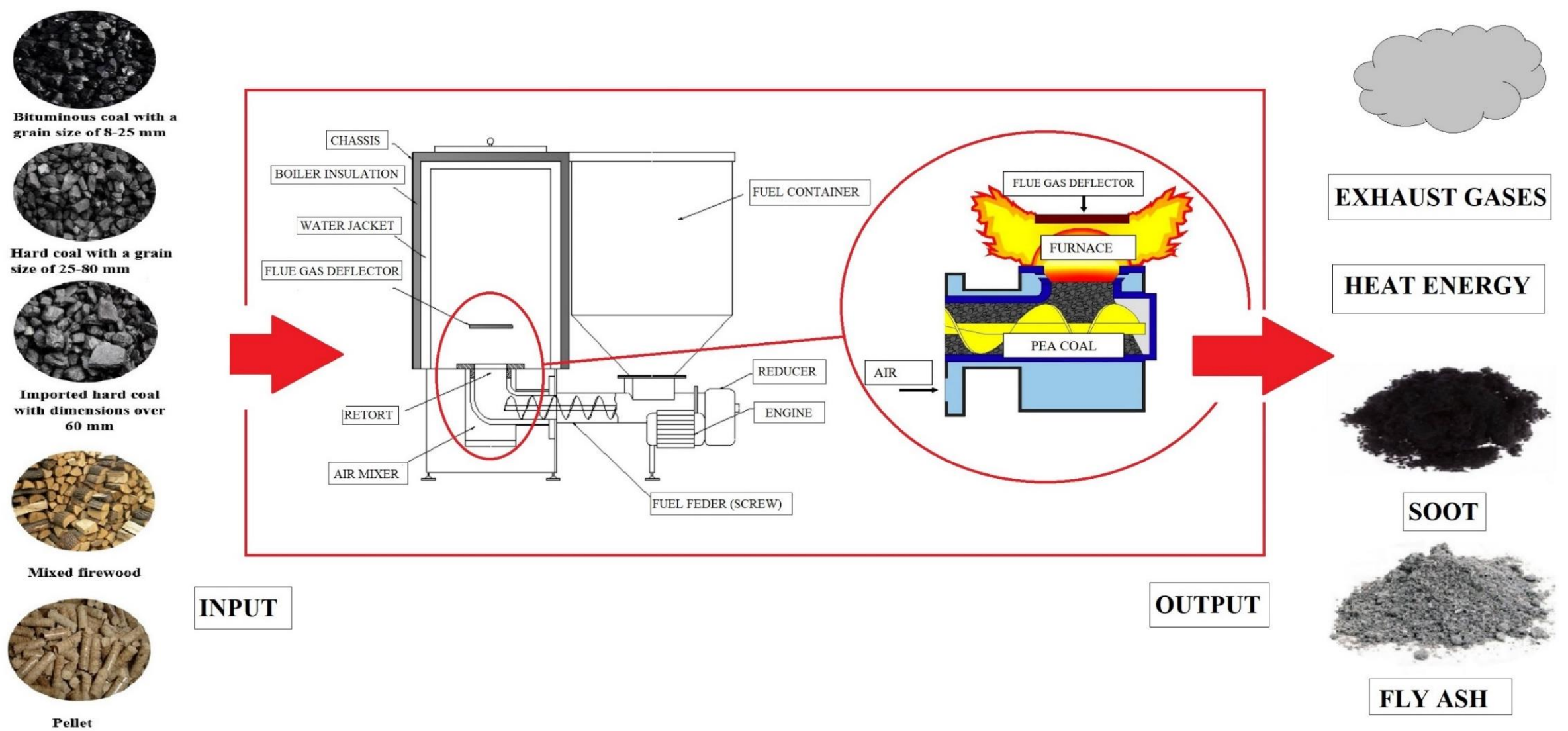

Figure 1. Scheme of testing system with all key elements. 
Then, after the combustion of the individual types of fuels, soot samples were collected. The soot is a side effect of the combustion process. About $3 \mathrm{~g}$ of soot was taken from the heat exchanger. The soot was extracted twice with a mixture of hexane-acetone solvents $(20 \mathrm{~mL} / 5 \mathrm{~mL})$ for $2 \mathrm{~h}$ to elute the PAH tested therein, i.e., naphthalene, acenaphthalene, anthracene, benzo(a)anthracene, benzo(b)fluoroanthrone, benzo(k)fluoroanthrone, benzo(g,h,i)perylene, benzo(a)pyrene, chrysene, dibano(a,h)anthracene, fluoroanthene, fluoren, indeno(1,2,3-c,d)pyrene, naphthalene, phenanthrene and pyrene. Acetone and polar compounds extracted from it were removed by washing twice with $10 \mathrm{~mL}$ of deionized water. The remaining organic phase was dried over anhydrous sodium sulfate (anhydrous, ACS reagent, $\geq 99 \%$ Sigma-Aldrich). The extracts were then concentrated on a Turbo-Vap apparatus under an inert gas ie. nitrogen atmosphere, to a volume of $1 \mathrm{~mL}$. The solutions prepared in this way were subjected to chromatographic analysis for the presence of aromatic hydrocarbons mentioned above. A gas chromatograph coupled with a mass spectrometer (Agilent GC/MS Triple Quad 7000 C) was used, equipped with a split/splitless dispenser and an HP-5MS capillary column measuring $30 \mathrm{~m} \times 0.25 \mathrm{~mm}$ with a film thickness of $0.25 \mu \mathrm{m}$. Working conditions of the apparatus during the analysis shown in Table 1.

Table 1. Chromatograph working conditions during polycyclic aromatic hydrocarbons (PAH) determination.

\begin{tabular}{cc}
\hline Working Conditions & Value \\
\hline carrier gas & helium with purity 6.0 \\
carrier gas flow rate through the column & $1 \mathrm{~mL} / \mathrm{min}$ (splitless) \\
volume of the injected sample & $1 \mu \mathrm{L}$ \\
dispenser temperature & $260^{\circ} \mathrm{C}$ \\
ion source temperature & $230{ }^{\circ} \mathrm{C}$ \\
transfer line temperature & $300^{\circ} \mathrm{C}$ \\
quadrupole temperature & $150{ }^{\circ} \mathrm{C}$ \\
scanning mode & single ion monitoring \\
The temperature program was set as follows \\
\hline initial temperature of the column furnace & $60{ }^{\circ} \mathrm{C}, 2$ min isothermal \\
temperature increase & $30{ }^{\circ} \mathrm{C} / \mathrm{min}$ to $120^{\circ} \mathrm{C}$, from $120^{\circ} \mathrm{C}$ temperature \\
increase $5{ }^{\circ} \mathrm{C} /$ min to $300{ }^{\circ} \mathrm{C}$
\end{tabular}

During the extraction, no internal standard addition was used, whereas the method control was carried out by simultaneous execution of the entire analytical procedure for a sample of certified reference material-Clean soil Reference Material EDF-5183 (CERILLIANT Analytical Reference Standards). The tests used external calibration with calibration curves for individual compounds. Calibration solutions were prepared from a standard of 16 PAH mixture (AccuStandard, Z-014G).

In order to determine the harmfulness of the $16 \mathrm{PAH}$ examined, indicators were used which define the toxicity of individual PAH and the whole group as well. A universal method for calculating the risk related to exposure to PAH mixture was adopted. $\mathrm{B}(\mathrm{a}) \mathrm{P}$ (benzo(a)pirene) is assumed to be a reference compound. The carcinogenic potential, called the toxicity equivalence factor (TEF) of other compounds is calculated relative to $\mathrm{B}(\mathrm{a}) \mathrm{P}$. The toxicity equivalent value (TEQ—-toxic equivalent) is the sum of the products of the concentrations of individual PAH and their relative toxicity coefficients $\mathrm{TEQ}=\mathrm{CEQ}[23]$ :

$$
\begin{gathered}
\mathrm{TEQ}=\mathrm{CEQ}=0.001 \times[\mathrm{Nap}]+0.001 \times[\mathrm{Acy}]+0.001 \times[\text { Ace }]+0.001 \times[\mathrm{Fl}]+0.001 \times[\mathrm{Phe}]+ \\
0.01 \times[\text { Ant }]+0.001 \times[\mathrm{Flu}]+0.001 \times[\mathrm{Pyr}]+0.1 \times[\mathrm{B}(\mathrm{a}) \mathrm{A}]+0.01 \times[\mathrm{Chr}]+0.1 \times[\mathrm{B}(\mathrm{b}) \mathrm{F}]+0.1 \times \\
{[\mathrm{B}(\mathrm{k}) \mathrm{F}]+1 \times[\mathrm{B}(\mathrm{a}) \mathrm{P}]+5 \times[\mathrm{D}(\mathrm{ah}) \mathrm{A}]+0.1 \times[\mathrm{B}(\mathrm{ghi}) \mathrm{P}]+0.1 \times[\mathrm{I}(\mathrm{cd}) \mathrm{P}] .}
\end{gathered}
$$

Durant and others [25] reported mutagenic coefficients for individual PAH. Wilellet and others [26] proposed that the carcinogenic potential of PAH may be calculated with respect to 
dioxin (2,3,7,8-tetrachlorodibenzo-p-dioxin-TCDD), for which the carcinogenicity coefficient value is equal to 1 . To assess the harmfulness of PAH, in addition to the CEQ toxicity equivalent (TEQ) given by Nisbet and LaGoy [23], the mutagenicity equivalent (MEQ) and carcinogenicity (TCDD-TEQ) are also used [24]. The mutagenicity factors [25] and carcinogenicity factors [26] were selected which refer to the 16 priority PAH according to the EPA list. The mutagenicity equivalent was given as the sum of the product of the concentration of individual PAH and their relative mutagenicity coefficients [24]:

$$
\begin{gathered}
\mathrm{MEQ}=0.00056 \times[\mathrm{Acy}]+0.082 \times[\mathrm{B}(\mathrm{a}) \mathrm{A}]+0.017 \times[\mathrm{Chr}]+0.25 \times[\mathrm{B}(\mathrm{b}) \mathrm{F}]+0.11 \times[\mathrm{B}(\mathrm{k}) \mathrm{F}]+1 \times \\
{[\mathrm{B}(\mathrm{a}) \mathrm{P}]+0.31 \times[\mathrm{I}(\mathrm{cd}) \mathrm{P}]+0.29 \times[\mathrm{D}(\mathrm{ah}) \mathrm{A}]+0.19 \times[\mathrm{B}(\mathrm{ghi}) \mathrm{P}] .}
\end{gathered}
$$

On the other hand, the equivalent of carcinogenicity is the sum of the products of the concentrations of individual PAH and their relative carcinogenicity coefficients:

$$
\begin{aligned}
\text { TCDD-TEQ }= & 0.000025 \times[\mathrm{B}(\mathrm{a}) \mathrm{A}]+0.00020 \times[\mathrm{Chr}]+0.000354 \times[\mathrm{B}(\mathrm{a}) \mathrm{P}]+0.00110 \times[\mathrm{I}(\mathrm{cd}) \mathrm{P}]+ \\
& 0.00203 \times[\mathrm{D}(\mathrm{ah}) \mathrm{A}]+0.00253 \times[\mathrm{B}(\mathrm{b}) \mathrm{F}]+0.00487 \times[\mathrm{B}(\mathrm{k}) \mathrm{F}] .
\end{aligned}
$$

The harmfulness of PAH is also expressed as the ratio of PAH considered carcinogenic to the sum of all PAH determined [27]:

$$
\begin{gathered}
\Sigma \mathrm{PAH} \text { arc } / \Sigma \mathrm{PAH}=([\mathrm{B}(\mathrm{a}) \mathrm{A}]+[\mathrm{B}(\mathrm{a}) \mathrm{P}]+[\mathrm{B}(\mathrm{b}) \mathrm{F}]+[\mathrm{B}(\mathrm{k}) \mathrm{F}]+[\mathrm{Chr}]+[\mathrm{D}(\mathrm{ah}) \mathrm{A}]+ \\
[\mathrm{I}(\mathrm{cd}) \mathrm{P}]) /([\Sigma 16 \mathrm{PAH}]) .
\end{gathered}
$$

Based on the calculated carcinogenicity and mutagenicity indicators, the toxicity of the tested types of solid fuels was determined. It was assumed that when the value of the ratio $\Sigma \mathrm{PAH}_{\mathrm{carc}} / \Sigma \mathrm{PAH}$ is closer to 1 , the PAH pose a greater threat to the population.

\section{Results and Discussion}

Table 2 shows the basic properties of the analyzed 16 polycyclic aromatic hydrocarbons: naphthalene, acenaphthalene, anthracene, benzo(a)anthracene, benzo(b)fluoroanthrone, benzo(k)fluoranthrene, benzo(g,h,i)perylene, benzo(a)pyrene, chrysene, dibenz(a,h)anthracene, fluoroanthene, fluoren, indeno $(1,2,3-\mathrm{c}, \mathrm{d})$ pyrene, naphthalene, phenanthrene and pyrene. The studied hydrocarbons were divided into three groups: $\Sigma$ LMW (hydrocarbons containing from two to four aromatic rings in their structure: naphthalene, acenaphthene, acenaphthalene, fluorene, phenanthrene, anthracene); $\Sigma$ HMW (five- and six-ring compounds: fluoranthene, pyrene, benzo(a)anthracene, chrysene, benzo(b)fluoranthene, benzo(k)fluoranthene, benzo(a)pyrene, indeno(1,2,3-c,d)pyrene, dibenz(a,h)anthracene and benzo(g,h,i)perylene) and the total of 16 aromatic hydrocarbons- $\Sigma 16 \mathrm{PAH}$.

Table 3 presents results of PAH content analysis in the studied soot samples from the combustion of selected fuels. PAH are the most frequently tested pollutants in environmental samples, which is dictated primarily by their negative impact on health, including toxicity, carcinogenicity and mutagenicity $[25,30,31]$. 
Table 2. $\Sigma$ PAH included hydrocarbons containing from two to six rings in their structure.

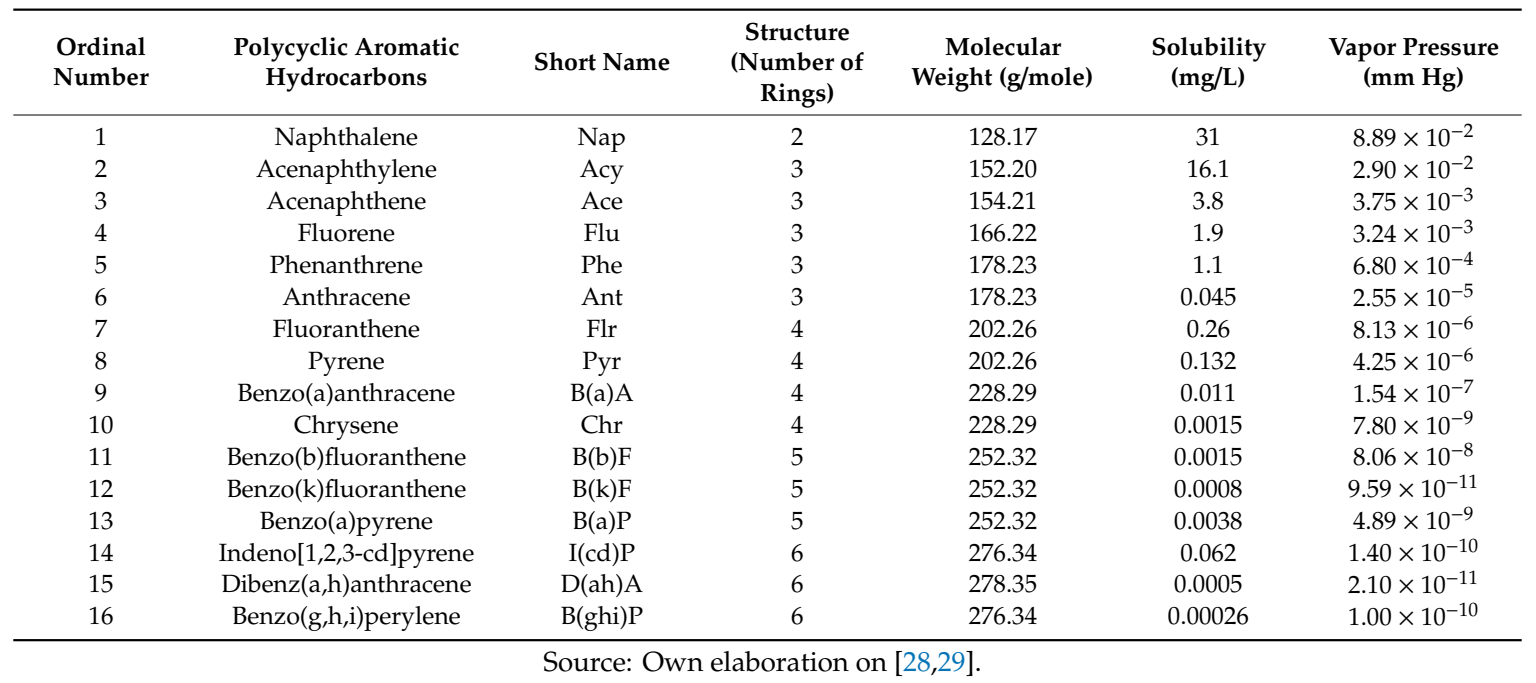

Table 3. Results of PAH determinations in soot samples from the combustion of solid fuels.

\begin{tabular}{|c|c|c|c|c|c|}
\hline $\mathrm{mg} / \mathrm{kg} \mathrm{DM}$ & Pellet $6 \mathrm{~mm}$ & Hard Coal $>60 \mathrm{~mm}$ & $\begin{array}{l}\text { Hard Coal } \\
25-80 \mathrm{~mm}\end{array}$ & $\begin{array}{l}\text { Hard Coal } \\
8-25 \mathrm{~mm}\end{array}$ & $\begin{array}{l}\text { Mixed } \\
\text { Firewood }\end{array}$ \\
\hline Naphthalene & $0.50 \pm 0.20$ & $2.52 \pm 3.04$ & $1.20 \pm 0.04$ & $2.17 \pm 0.46$ & $1.33 \pm 0.08$ \\
\hline Acenaphthene & $0.05 \pm 0.002$ & $1.28 \pm 1.62$ & $0.29 \pm 0.03$ & $0.59 \pm 0.26$ & $0.15 \pm 0.02$ \\
\hline Fluorene & $0.07 \pm 0.002$ & $9.62 \pm 13.34$ & $0.86 \pm 0.08$ & $7.71 \pm 9.23$ & $0.27 \pm 0.02$ \\
\hline Phenanthrene & $2.87 \pm 0.12$ & $50.05 \pm 12.44$ & $47.5 \pm 5.69$ & $52.49 \pm 11.67$ & $18.82 \pm 2.45$ \\
\hline Pyrene & $5.23 \pm 0.61$ & $16.42 \pm 2.51$ & $41.12 \pm 5.39$ & $32.01 \pm 9.68$ & $11.84 \pm 1.90$ \\
\hline Benzo(a)anthracene & $3.70 \pm 0.09$ & $13.05 \pm 9.14$ & $26.17 \pm 3.86$ & $18.84 \pm 5.65$ & $8.44 \pm 1.27$ \\
\hline Chrysene & $4.52 \pm 0.11$ & $12.04 \pm 7.09$ & $24.07 \pm 3.61$ & $17.09 \pm 5.07$ & $8.73 \pm 1.24$ \\
\hline Benzo(b)fluoranthene & $13.07 \pm 3.97$ & $22.40 \pm 7.40$ & $33.09 \pm 5.78$ & $29.04 \pm 8.70$ & $32.87 \pm 5.29$ \\
\hline Benzo(k)fluoranthene & $15.58 \pm 0.55$ & $27.02 \pm 12.85$ & $49.58 \pm 7.77$ & $44.49 \pm 12.95$ & $28.03 \pm 4.50$ \\
\hline Benzo(g,h,i)perylene & $13.01 \pm 1.95$ & $12.93 \pm 2.63$ & $22.12 \pm 3.19$ & $30.16 \pm 5.60$ & $23.48 \pm 1.50$ \\
\hline$\Sigma 16 \mathrm{PAH}$ & $95.62 \pm 6.44$ & $263.36 \pm 91.00$ & $418.21 \pm 61.03$ & $412.70 \pm 127.16$ & $230.44 \pm 28.62$ \\
\hline$\Sigma \mathrm{LMW}$ & $4.90 \pm 0.42$ & $87.81 \pm 24.89$ & $71.86 \pm 6.24$ & $95.26 \pm 32.92$ & $28.01 \pm 2.81$ \\
\hline$\Sigma \mathrm{HMW}$ & $90.72 \pm 5.99$ & $175.55 \pm 60.16$ & $346.35 \pm 52.67$ & $317.43 \pm 58.32$ & $188.26 \pm 25.31$ \\
\hline
\end{tabular}

As a result of chromatographic analysis of extracts from black carbon samples, it was found that the sum of 16 determined hydrocarbons included in the PAH group depends significantly on the type of fuel burned while maintaining the same combustion conditions. The total PAH content in fuel samples ranged from $95.62 \pm 6.44 \mathrm{mg} / \mathrm{kg} \mathrm{DM}$ in the case of combustion of pellets with a grain size of $6 \mathrm{~mm}$ to $418.21 \pm 61.03 \mathrm{mg} / \mathrm{kg} \mathrm{DM}$ in the case of coal combustion with a grain size of 25-80 mm. Relative uncertainty of each of the PAH sum assays within the framework of separate combustion for individual fuels was estimated from $6 \%$ to $34 \%$, which means that the combustion process is characterized by high variability and nonlinearity, even while maintaining the same fuel and combustion parameters [32].

Analyzing the content of the sum of $16 \mathrm{PAH}$ (Figure 2), the smallest content in the soot in the samples was from pellet combustion and was found to be $95.62 \pm 6.44 \mathrm{mg} / \mathrm{kg} \mathrm{DM}$. Another fuel, which was characterized by the second lowest PAH content, was mixed wood fuel, for which $230.44 \pm 28.62 \mathrm{mg} / \mathrm{kg}$ DM was obtained. The remaining three analyzed fuels were hard coal with different granulation. Soot samples from the combustion of selected hard coals were characterized by much higher PAH content as compared to soot samples from the combustion of pellets and mixed 
wood fuel. In the group of coals, the highest total PAH content was found in soot samples from the combustion of coal with a grain size of $25-80 \mathrm{~mm}$, which was $418.21 \pm 61.03 \mathrm{mg} / \mathrm{kg} \mathrm{DM}$, while the smallest content was characterized by soot samples from coal combustion granulation $>60 \mathrm{~mm}$, which was $263.36 \pm 91.00 \mathrm{mg} / \mathrm{kg}$ DM. Soot from coal combustion with large irregular cubes over $60 \mathrm{~mm}$ was characterized by a lower content of PAH not only from black carbon from 25-80 mm granulation, but also from coal with $8-25 \mathrm{~mm}$ granulation.

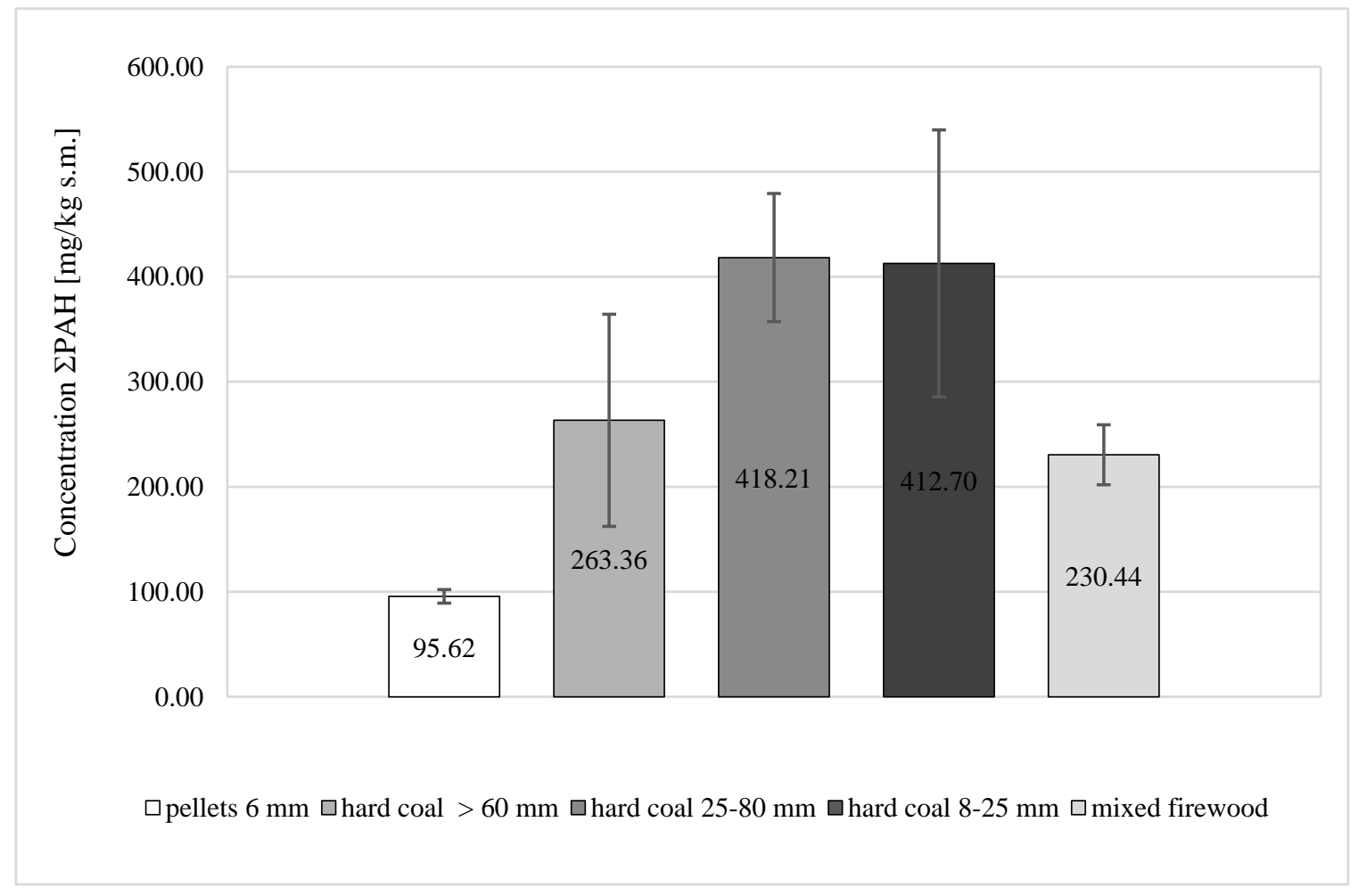

Figure 2. Average content of $\Sigma \mathrm{PAH}$ in soot samples from the combustion of selected fuels.

Research conducted by Kakareka on the emission of polycyclic aromatic hydrocarbons (PAH) from several types of solid fuel combustion in various low power boilers in Belarus proved that the highest PAH emissions were detected in waste gases from the incineration of household waste and wood waste. The lowest PAH emissions originated from the combustion of peat briquettes. A difference was observed in the concentrations of the total PAH in the waste gases from the combustion of solid fuels depending on the type of boiler. The PAH content from birch wood combustion was higher than in the case of pine wood emissions [33].

When analyzing the compactness of light PAH fraction, determined with the abbreviation LMW (Figure 3) and containing hydrocarbons consisting of two and three aromatic rings, it was found that soot from the combustion of pellets and mixed fuel wood contains, as in the case of a total of $16 \mathrm{PAH}$, the least LMW; these values were $4.90 \pm 0.42 \mathrm{mg} / \mathrm{kg}$ DM and $18.01 \pm 2.81 \mathrm{mg} / \mathrm{kg} \mathrm{DM}$, respectively. These values represented only $5 \%$ of the total PAH content for pellets and $12 \%$ for firewood. The content of $\Sigma$ LMW in soot samples from hard coal combustion was much higher than in the case of pellets and firewood. The highest content of $\Sigma$ LMW was obtained in soot samples from the combustion of coal with 8-25 mm granulation and it amounted to $95.26 \pm 32.92 \mathrm{mg} / \mathrm{kg}$ DM, which constituted $23 \%$ of the total PAH content. However, in the samples after combustion of coal with a granulation of $25-80 \mathrm{~mm}$ and coal with a granulation above $60 \mathrm{~mm}$, the $\Sigma \mathrm{LMW}$ contents were $71.86 \pm 6.24 \mathrm{mg} / \mathrm{kg} \mathrm{DM}$ and $87.81 \pm 24.89 \mathrm{mg} / \mathrm{kg} \mathrm{DM}$, respectively. These contents for coal of $25-80 \mathrm{~mm}$ granulation and coal of $>60 \mathrm{~mm}$ granulation constituted $17 \%$ and $33 \%$ of their total PAH content, respectively. 


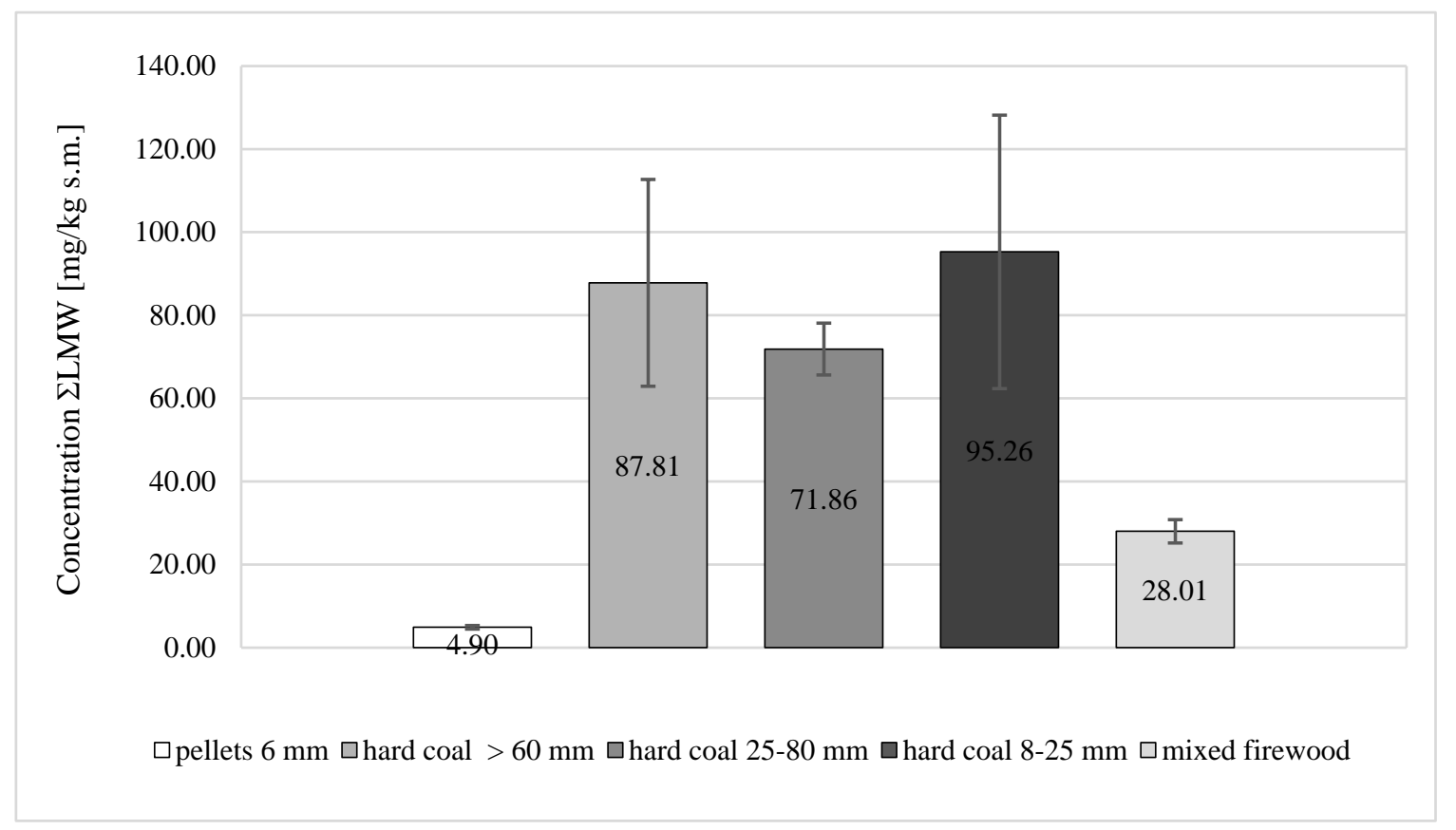

Figure 3. Average content of $\Sigma \mathrm{LMW}$ in soot samples from the combustion of selected fuels.

This information indicates that among the coals, the combustion of bituminous coal with a grain size of $25-80 \mathrm{~mm}$ is the most advantageous as it contains the largest percentage of light aromatic hydrocarbons, yet the highest $\Sigma \mathrm{PAH}$. Thus, it contains the lowest percentage of light aromatic hydrocarbons. Compounds from the PAH group are the more biodegradable the easier their construction is [34].

Results of the heavier PAH fraction, the so-called HMW (Figure 4) which includes hydrocarbons with four or more rings [35], showed that the percentages of HMW in the case of samples of solid fuels from wood biomass were $95 \%$ for pellets and $88 \%$ for mixed firewood. In the case of coal samples, the percent contents of heavier PAH were $67 \%$ for hard coal with a grain size exceeding $60 \mathrm{~mm}, 83 \%$ for hard coal with a grain size of $25-80 \mathrm{~mm}$ and $77 \%$ for hard coal $8-25 \mathrm{~mm}$. A higher percentage of PAH with higher molecular weights, i.e., having at least four aromatic rings in their molecule, accounted for more than $50 \%$ in each of the analyzed solid fuels. These hydrocarbons are characterized by higher durability in the environment compared to hydrocarbons with lower masses. This property is related to their lower solubility in water as well as the volatility described by Henry's constant. Both values decrease with the increase of molecular mass, while their value depends on the intensity of PAH elimination through biochemical changes and evaporation [36].

From Figures 2-4, hard coals $25-80 \mathrm{~mm}$ and $8-25 \mathrm{~mm}$ have very similar performance in $\Sigma \mathrm{PAH}$, $\Sigma$ LMW and $\Sigma$ HMW. It seems that within the whole grain size range of $8-80 \mathrm{~mm}$, soot emission does not depend on grain size. While on the other hand, grains $>60 \mathrm{~mm}$ have clearly lower $\Sigma \mathrm{PAH}$ and $\Sigma$ HMW. It is possible that these differences result from the properties of hard coal, e.g., the moisture content of coal. 


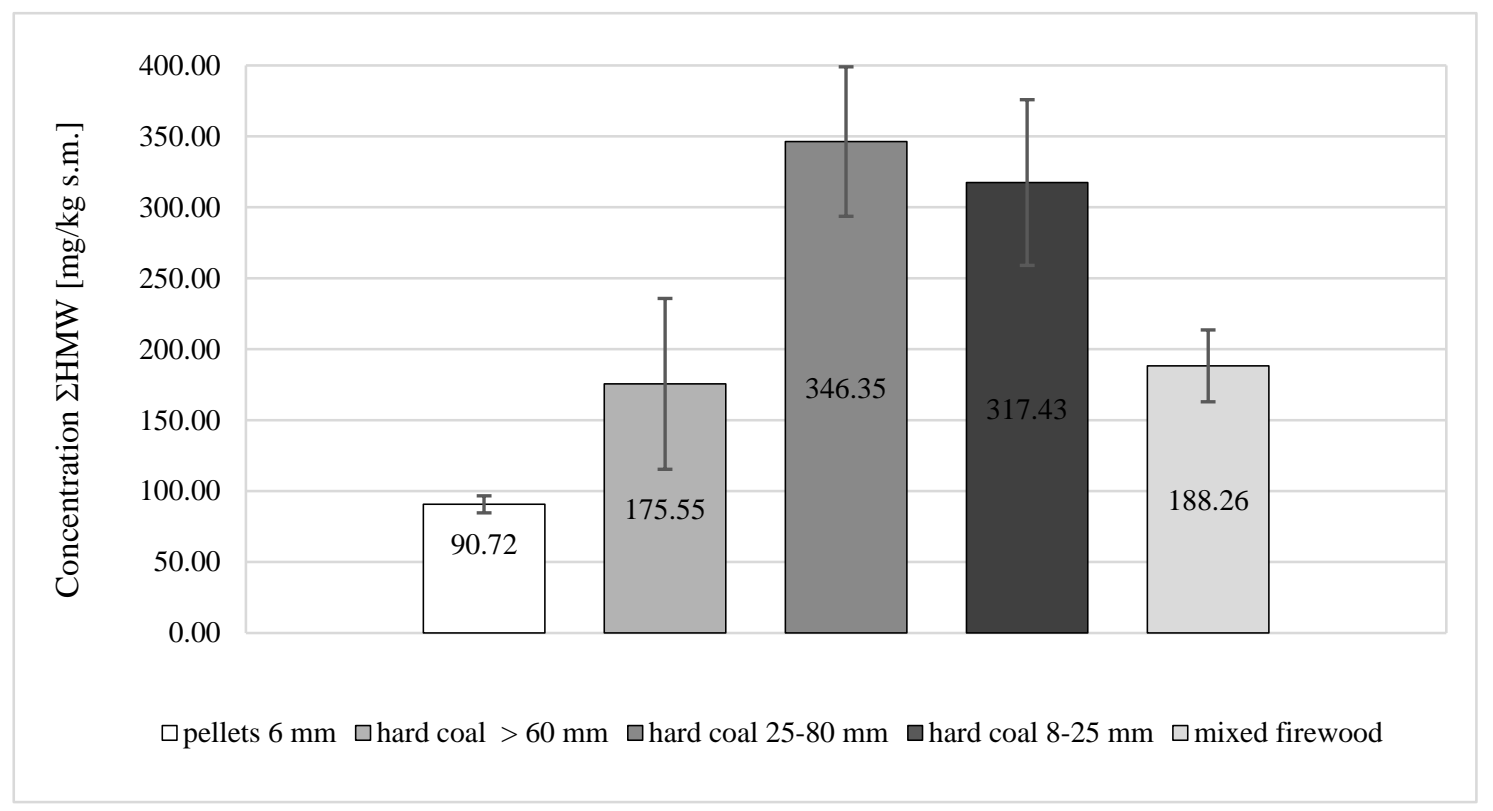

Figure 4. Average content of $\Sigma \mathrm{HMW}$ in soot samples from the combustion of selected fuels.

In addition, taking into account that individual PAH show very diversified degrees of carcinogenicity, the equivalent values of TEQ toxicity were determined (Table 4), which characterize the total toxicity of the test compounds relative to the indicator benzo(a)pyrene. The value of the TEQ toxicity equivalent depends primarily on the PAH content with high TEF toxicity ratios [37]. The highest equivalents of toxicity characterized soot from the combustion of hard coal with a grain size of $25-80 \mathrm{~mm}$ and hard coal of 8-25 mm, amounting to $158.76 \pm 23.34 \mathrm{mg} / \mathrm{kg} \mathrm{DM}$ and $158.53 \pm 31.77 \mathrm{mg} / \mathrm{kg} \mathrm{DM}$, respectively. This means that although both soot types have similar contents of $16 \mathrm{PAH}$, the soot from combustion of coal with a granulation of $25-80 \mathrm{~mm}$ contains more carcinogenic homologs. Whereas, the soot coming from the combustion of wood pellets with a grain size of $6 \mathrm{~mm}$ had the smallest value of toxicity equivalent, which was $28.39 \pm 1.19 \mathrm{mg} / \mathrm{kg}$ DM. The highest mutagenic equivalent (Table 3) was also obtained for soot derived from the combustion of bituminous coal $80 \mathrm{~mm}(94.28 \pm 15.47 \mathrm{mg} / \mathrm{kg}$ $\mathrm{DM})$ and hard coal 9-25 mm $(93.93 \pm 16.65 \mathrm{mg} / \mathrm{kg} \mathrm{DM})$, and the lowest was for soot obtained from the combustion of pellets $(26.02 \pm 1.68 \mathrm{mg} / \mathrm{kg} \mathrm{DM})$.

Table 4. Mean values of the four risk indicators (CEQ, MEQ, TCDD-TEQ and $\left.\Sigma \mathrm{PAH}_{\mathrm{carc}} / \Sigma \mathrm{PAH}\right)$ in soot samples.

\begin{tabular}{cccccc}
\hline Indicator & Pellet $\mathbf{6 ~} \mathbf{~ m m}$ & Hard Coal $\mathbf{7} \mathbf{6 0} \mathbf{~ m m}$ & $\begin{array}{c}\text { Hard Coal } \\
\mathbf{2 5 - 8 0} \mathbf{~ m m}\end{array}$ & $\begin{array}{c}\text { Hard Coal } \\
\mathbf{8 - 2 5} \mathbf{~ m m}\end{array}$ & $\begin{array}{c}\text { Mixed } \\
\text { Firewood }\end{array}$ \\
\hline $\mathrm{TEQ}=\mathrm{CEQ}$ & $28.39 \pm 1.19$ & $103.06 \pm 37.95$ & $158.76 \pm 23.34$ & $158.53 \pm 31.77$ & $90.16 \pm 11.12$ \\
$\mathrm{MEQ}$ & $26.02 \pm 1.68$ & $50.22 \pm 13.47$ & $94.28 \pm 15.47$ & $93.93 \pm 16.65$ & $64.93 \pm 8.56$ \\
$\mathrm{TCDD}-\mathrm{TEQ}$ & $0.19 \pm 0.01$ & $0.33 \pm 0.06$ & $0.61 \pm 0.09$ & $0.55 \pm 0.11$ & $0.39 \pm 0.06$ \\
$\Sigma \mathrm{PAH}$ & $0.60 \pm 0.15$ & $0.56 \pm 0.01$ & $0.53 \pm 0.01$ & $0.66 \pm 0.02$ \\
\hline
\end{tabular}

The fuels selected for the analysis of PAH emission differed in their calorific value, i.e., in the amount of heat emitted during combustion of a mass unit or a volume unit of fuel during its total and complete combustion. According to producers of examined fuels: hard coal with dimensions over $60 \mathrm{~mm}$ emits $29 \mathrm{MJ} / \mathrm{kg}$, hard coal with a grain size of 25-80 mm emits $26 \mathrm{MJ} / \mathrm{kg}$, bituminous coal with a grain size of $8-25 \mathrm{~mm}$ emits $23 \mathrm{MJ} / \mathrm{kg}$, pellets with a grain size of $6 \mathrm{~mm}$ emits $17 \mathrm{MJ} / \mathrm{kg}$ and mixed firewood emits $15 \mathrm{MJ} / \mathrm{kg}$. Calculation of PAH emission from soot for the unit (MJ) of released energy during combustion of tested fuels reached such values as: hard coal with dimensions over $60 \mathrm{~mm}, 9.08 \mathrm{mg}$ PAH/MJ; hard coal with a grain size of 25-80 mm, $16.09 \mathrm{mg}$ PAH/MJ; bituminous coal 
with a grain size of $8-25 \mathrm{~mm}, 17.91 \mathrm{mg}$ PAH/MJ; pellets with a grain size of $6 \mathrm{~mm}, 5.58 \mathrm{mg}$ PAH/MJ; and mixed firewood, $15.36 \mathrm{mg}$ PAH/MJ. The lowest PAH emissions per calorific value were obtained for pellets and the highest were obtained in the case of bituminous coal with a grain size of $8-25 \mathrm{~mm}$.

On the other hand, when comparing the toxicity equivalent of soot samples with combustion of fuels, the highest one was obtained for soot samples from hard coal combustion with granulation of $25-80 \mathrm{~mm}(0.61 \pm 0.09 \mathrm{mg} / \mathrm{kg} \mathrm{DM})$. The next largest was the equivalent calculated for soot samples from the combustion of black coal 8-25 mm $(0.55 \pm 0.11 \mathrm{mg} / \mathrm{kg} \mathrm{DM})$, then for samples from burning mixed fuel wood $(0.39 \pm 0.06 \mathrm{mg} / \mathrm{kg} \mathrm{DM})$ and further for combustion samples of the hard coal $>60 \mathrm{~mm}$ $(0.33 \pm 0.06 \mathrm{mg} / \mathrm{kg} \mathrm{DM})$. The smallest TCDD-TEQ was obtained in the case of samples from 6-mm pellet combustion, which was $0.19 \pm 0.01 \mathrm{mg} / \mathrm{kg}$ DM. Analyzing the ratio of PAH considered carcinogenic to the sum of all PAH (Table 3) in the soot samples, it was found that the soot from the combustion of 6-mm pellets had the highest ratio $(0.70 \pm 0.02)$, with the soot from the combustion of mixed fuel wood classified as the next highest $(066 \pm 0.02)$. The smallest ratio $\Sigma \mathrm{PAH}_{\text {carc }} / \Sigma \mathrm{PAH}$ was obtained in the case of soot samples from the combustion of black coal 8-25 mm $(0.53 \pm 0.01)$. Despite the lowest TEQ, MEQ and TCDD-TEQ coefficients for soot from the combustion of pellets with a grain size of $6 \mathrm{~mm}$, the highest ratio of carcinogenic PAH to the total PAH was obtained for this soot, which proves that the more carcinogenic PAH homologues are predominant.

Research results presented in this manuscript show a very significant impact on the content of mutagenic and toxic compounds such as PAH in soot, which is affected by the type of solid fuel burned in household furnaces. Reduction of PAH emissions in soot particles is extremely important due to the occurrence of adverse health effects [29]. The National Agency for Research on Cancer (IARC) has identified benzo(a)pyrene as a group of compounds with proven carcinogenicity (IARC 2012). Carcinogenic compounds are non-threshold substances, which entail the risk of cancer changes upon exposure to any substance concentration [38]. It is necessary to conduct activities to limit the exposure of the population to these compounds. The most effective process could be the elimination of low-emission sources by changing the way apartments and houses are heated, because coal burning in the municipal sector is still the most important source of PAH emissions. On the basis of the conducted research, it was stated that hard coal, regardless of the form in which it is adapted for combustion, whether it is in a form of large cubes with granulation over $60 \mathrm{~mm}$ or walnut-type fine coal with granulation of $25-80 \mathrm{~mm}$ or also eco-pea coal, which is adapted to combustion in boilers equipped with an automatic feeder, which evenly dispenses the material, generates higher amounts of PAH in soot than the combustion of biomass in the form of mixed firewood or 6-mm pellets.

\section{Conclusions}

1. Among the examined soot samples from the combustion of solid fuels, the lowest PAH concentration was obtained in soot samples from combustion of 6-mm pellets $(95.62 \pm 6.44 \mathrm{mg} / \mathrm{kg}$ $\mathrm{DM})$, and the highest was obtained for $25-80 \mathrm{~mm}$ coal $(418.21 \pm 61.03 \mathrm{mg} / \mathrm{kg} \mathrm{DM})$, which was over 4 times higher than in the case of 6-mm pellets.

2. Analysis of the compactness of the light LMW fraction showed that the smallest share of this fraction in the total concentration was recorded in samples of 6-mm pellets, representing only $5 \%$ of the total PAH total. This fraction was measured to be $12 \%$ for firewood. In the case of coals, much higher percentages of the LMW fraction were obtained.

3. Higher percentages of PAH with higher molecular weights, i.e., the HMW fraction, accounted for more than $50 \%$ in each of the analyzed solid fuels.

4. Considering the calculated TEQ $=$ CEQ, MEQ and TCDD-TEQ indicators, it was found that the most toxic and carcinogenic is black carbon with the granulation of $25-80 \mathrm{~mm}$, while soot samples from combustion 6-mm pellets.

5. The largest ratio of $\Sigma \mathrm{PAH}_{\mathrm{carc}} / \Sigma \mathrm{PAH}$ was obtained in the case of soot samples from the combustion of 6-mm pellets, while the smallest was from the combustion of coal with a granulation of $8-25 \mathrm{~mm}$. 
Author Contributions: E.S. and I.S.; methodology, E.S.; validation, E.S. formal analysis, E.S. data curation, E.S.; writing-original draft preparation, I.S. writing-review and editing, E.S. visualization, I.S.; supervision, I.S. project administration, E.S. funding acquisition.

Funding: The research was carried out as part of research work No. MB/WBIIS/12/2018 and No. WZ/WBiIS/8/2019 at the Białystok University of Technology and financed from a subsidy provided by the Ministry of Science and Higher Education.

Conflicts of Interest: The authors declare no conflict of interest.

\section{References}

1. Skotak, K.; Degórska, A.; Ulańczyk, R.; Pecka, T. Soot as an indicator of human activity for life and environment. Chem. Ind. 2016, 95, 548-553. [CrossRef]

2. Vershinina, K.Y.; Kuznetsov, G.V.; Strizhak, P.A. Ignition Characteristics of Coal-Water Slurry Containing Petrochemicals Based on Coal of Varying Degrees of Metamorphism. Energy Fuels 2016, 30, 6808. [CrossRef]

3. Dzikuć, M.; Kułyk, P.; Dzikuć, M.; Urban, S.; Piwowar, A. Associated with Low Emission Reductions in Poland's Lubuskie Voivodeship. Pol. J. Environ. Stud. 2019, 28, 65-72. [CrossRef]

4. Schulz, F.; Commodo, M.; Kaiser, K.; De Falco, G.; Minutolo, P.; Meyer, G.; Gross, L.; Anna, A.D. Insights into incipient soot formation by atomic force microscopy. Proc. Combust. Inst. 2019, 37, 885-892. [CrossRef]

5. Commodo, M.; Kaiser, K.; De Falco, G.; Minutolo, P.; Schulz, F.; Leo Gross, A.D.A. On the early stages of soot formation: Molecular structure elucidation by high-resolution atomic force microscopy. Combust. Flame 2019, 205, 154-164. [CrossRef]

6. Michelsen, H.A. Probing soot formation, chemical and physical evolution, and oxidation: A review of in situ diagnostic techniques and needs. Proc. Combust. Inst. 2017, 36, 717-735. [CrossRef]

7. European Environment. The European Environment State and Outlook 2015 Synthesis Report; Environmental Protection Agency (EPA): Copenhagen, Denmark, 2015.

8. Zhan, C.; Zhang, J.; Zheng, J. Characterization of carbonaceous fractions in PM2.5 and PM10 over a typical industrial city in central China. Environ. Sci. Pollut. Res. 2019, 26, 16855. [CrossRef]

9. Fernandes, M.B.; Brooks, P. Characterization of carbonaceous combustion residues: II. Nonpolar organic compounds. Chemosphere 2003, 53, 447-448. [CrossRef]

10. Lokeshappa, B.; Dikshit, A.K. Fate of metals in coal fly ash ponds. Int. Conf. Environ. Sci. Dev. 2012, 3, 43-48.

11. Status of Black Carbon Monitoring in Ambient Air in Europe; Technical Report No 18/2013; European Environment Agency (EEA): Copenhagen, Denmark, 2013.

12. Maricq, M.M.; Xu, N. The effective density and fractal dimension of soot particles from premixed flames and motor vehicle exhaust. J. Aerosol Sci. 2004, 35, 1251-1274. [CrossRef]

13. Wainwright, M.; Alharbi, S.; Wickramasinghe, N.C. How do microorganisms reach the stratosphere? Int. J. Astrobiol. 2006, 5, 1-3. [CrossRef]

14. Lewtas, J. Air pollution combustion emissions: Characterization of causativeagents and mechanisms associated with cancer, reproductive, and cardiovascular effects. Mutat. Res. 2007, 636, 95-133. [CrossRef]

15. Tiwari, S.; Pipal, A.S.; Srivastava, A.K.; Bisht, D.S.; Pandithurai, G. Determination of wood burning and fossil fuel contribution of black carbon at Delhi, India using aerosol light absorption technique. Environ. Sci. Pollut. Res. 2015, 22, 2846. [CrossRef]

16. Pope, C.A.; Ezzati, M.; Dockery, D. Fine-Particulate Air Pollution and Life Expectancy in the United States. N. Engl. J. Med. 2009, 360, 376-386. [CrossRef]

17. Pratt, M.M.; John, K.; MacLean, A.B.; Afework, S.; Phillips, D.H.; Poirier, M.C. Polycyclic aromatic hydrocarbon (PAH) Exposure and DNA adduct semi-quantitation in archived human tissues. Int. J. Environ. Res. Public Health 2011, 8, 2675-2691. [CrossRef]

18. Anenberg, S. Technology: Clean stoves benefit climate and health. Nature 2012, 490, 343. [CrossRef]

19. Schmidt, C.W. Black carbon: The dark horse of climate change drivers. Environ. Health Perspect. 2011, 119, A172-A175. [CrossRef]

20. Kubica, R.; Kubica, K.; Kacprzyk, W. Limitation of black carbon emissions from solid fuel combustion in small plants. Chem. Ind. 2016, 95, 472-479. [CrossRef] 
21. Poland's National Inventory Report 2019 Greenhouse Gas Inventory for 1988-2017. Available online: https://www.google.com.hk/url?sa=t\&rct=j\&q=\&esrc=s\&source=web\&cd=1\&ved= 2ahUKEwiNsaLm1tnlAhWp-GEKHbupDqwQFjAAegQIAhAC\&url=https\%3A\%2F\%2Fwww.kobize.pl\% 2Fuploads\%2Fmaterialy\%2Fmaterialy_do_pobrania\%2Fkrajowa_inwentaryzacja_emisji\%2FNIR_POL_ 2019_23.05.2019.pdf\&usg=AOvVaw0uTJTEVB488hep1GpokGdt (accessed on 6 October 2019).

22. Dołżyńska, M.; Obidziński, S.; Kowczyk-Sadowy, M.; Krasowska, M. Densification and Combustion of Cherry Stones. Energies 2019, 12, 3042. [CrossRef]

23. Nisbet, I.C.T.; LaGoy, P.K. Toxic equivalency factors (TEFs) for polycyclic aromatic hydrocarbons (PAHs). Regul. Toxicol. Pharmacol. 1992, 16, 290-300. [CrossRef]

24. Rogula-Kozłowska, W.; Kozielska, B.; Klejnowski, K. Concentration, origin and health hazard from fine particle-bound PAH at three characteristic sites in Southern Poland. Bull. Environ. Contam. Toxicol. 2013, 91, 349-355. [CrossRef]

25. Durant, J.L.; Busby, W.F., Jr.; Lafleur, A.L.; Penman, B.W.; Crespi, C.L. Human cell mutagenicity of oxygenated, nitrated and unsubstituted polycyclic aromatic hydrocarbons associated with urban aerosols. Mutat. Res. Genet. Toxicol. 1996, 371, 123-157. [CrossRef]

26. Willett, K.L.; Gardinali, P.R.; Sericano, J.L.; Wade, T.L.; Safe, S.H. Characterization of the H4IIE rat hepatoma cell bioassay for evaluation of environmental samples containing polynuclear aromatic hydrocarbons (PAHs). Arch. Environ. Contam. Toxicol. 1996, 32, 442-448. [CrossRef]

27. Bourotte, C.; Forti, M.C.; Taniguchi, S.; Bícego, M.C.; Lotufo, P.A. A wintertime study of PAHs in fine and coarse aerosols in São Paulo city, Brazil. Atmos. Environ. 2005, 39, 3799-3811. [CrossRef]

28. Biache, C.; Mansuy-Huault, L.; Faure, P. Impact of oxidation and biodegradation on the most commonly used polycyclic aromatic hydrocarbons (PAH) diagnostic ratios: Implications for the source identification. J. Hazard. Mater. 2014, 267, 31-39. [CrossRef]

29. Kubiak, S.M. Polycyclic Aromatic Hydrocarbons (PAHs) - their occurrence in the environment and food. Probl. Hig. Epidemiol. 2013, 94, 31-36.

30. Kim, K.H.; Jahan, S.A.; Kabir, E.; Brown, R.J.C. A review of airborne polycyclic aromatic hydrocarbons (PAHs) and their human health effects. Environ. Int. 2013, 60, 71-80. [CrossRef]

31. Jyethi, D.S.; Khillare, P.S.; Sarkar, S. Risk assessment of inhalation exposure to polycyclic aromatic hydrocarbons in school children. Environ. Sci. Pollut. Res. 2014, 21, 366-378. [CrossRef]

32. Wójcik, W.; Kotyra, A.; Smolarz, A.; Gromaszek, K. Modern methods of monitoring and control of the solid fuels combustion process in order to reduce its impact on the natural environment. Annu. Set Environ. Prot. 2011, 13, 1559-1576.

33. Kakareka, S.V.; Kukharchyk, T.I.; Khomich, V.S. Study of PAH emission from the solid fuels combustion in residential furnaces. Environ. Pollut. 2005, 133, 383-387. [CrossRef]

34. Oleszczuk, P.; Baran, S. Degradation of individual polycyclic aromatic hydrocarbons (PAHs) in soil polluted with aircraft fuel. Pol. J. Environ. Stud. 2003, 12, 431-437.

35. Lamichhane, S.; Krishna, K.C.; Sarukkalige, R. Polycyclic aromatic hydrocarbons (PAHs) removal by sorption: A review. Chemosphere 2016, 148, 336-353. [CrossRef]

36. Kamińska, G.; Kudlek, E.; Dudziak, M.; Bohdziewicz, J. Removal and fate of PAHs during mechanical-biological wastewater treatment. Proc. ECOpole 2016, 10, 653-660. [CrossRef]

37. Kozielska, B.; Rogula-Kozłowska, W.; Rogula-Kopiec, P.; Jureczko, I. Polycyclic Aromatic Hydrocarbons in different airborne particulate matter fractions of areas dominated by communication emissions. Ecol. Eng. 2016, 49, 25-32. [CrossRef]

38. Brzeźnicki, S.; Bonczarowska, M.; Gromiec, J.P. Maximum levels for Polycyclic Aromatic Hydrocarbons (PAHs). Current legal situation and proposed amendments. Med. Pr. 2009, 60, 179-185.

(C) 2019 by the authors. Licensee MDPI, Basel, Switzerland. This article is an open access article distributed under the terms and conditions of the Creative Commons Attribution (CC BY) license (http://creativecommons.org/licenses/by/4.0/). 